УДК 37.091.12:005.963

\title{
Наталія Євтушенко
}

кандидат педагогічних наук, доцент Чернігівського обласного інституту післядипломної педагогічної освіти ім. К. Д. Ушинського

E-mail:env_2006@ukr.net

\section{НАУКОВИЙ ТЕЗАУРУС СИСТЕМИ ВДОСКОНАЛЕННЯ ВЧИТЕЛІВ ПРИРОДНИЧО-МАТЕМАТИЧНИХ ПРЕДМЕТІВ РЕСПУБЛІКИ ПОЛЬЩА}

Анотація: У статті розглядаються категорії та поняття, щзо входять до наукового тезауруса системи вдосконалення вчителів природничо-математичних предметів Республіки Польщз. Описано повний і систематизований перелік дефініцій для уточнення базового поняття «вчитель». Автором обгрунтовується актуальність деталізації тезауруса системи вдосконалення вчителів у науковому просторі Польщі краӥни, щяо входить до Свропейського Союзу - з метою використання ї̈ позитивного досвіду у прочесі розбудови системи підвищення кваліфікації педагогів у післядипломній освіті України.

Ключові слова: учитель, учитель природничо-математичних предметів, система вдосконалення вчителів, підготовка вчителів.

\section{Nataliia Yevtushenko}

Ph.D., Associate Professor Chernigov Regional Institute of Postgraduate Pedagogical Education named after K. D. Ushinskogo

E-mail: env_2006@ukr.net

\section{SCIENTIFIC THESAURUS OF THE SYSTEM OF IMPROVEMENT OF TEACHERS OF NATURAL AND MATHEMATICAL SUBJECTS OF THE REPUBLIC OF POLAND}

\begin{abstract}
The article reveals the categories and concepts included in the scientific thesaurus of the system of training of teachers of natural and mathematical subjects in the Republic of Poland. A complete and systematic list of definitions is described to clarify the basic concept of "a teacher". The author substantiates the relevance of the refinement of the thesaurus of the in-service teacher training system in the scientific space of Poland, a country of the European Union, with the aim of using its positive experience in the process of developing a system of teacher training in postgraduate education in Ukraine.

Key words: a teacher, a teacher of natural and mathematical subjects, a system of teachers' development, teacher training.
\end{abstract}

\section{Наталья Евтушенко}

\section{НАУЧНЫЙ ТЕЗАУРУС СИСТЕМЫ СОВЕРШЕНСТВОВАНИЯ УЧИТЕЛЕЙ ЕСТЕСТВЕННО-МАТЕМАТИЧЕСКИХ ПРЕДМЕТОВ РЕСПУБЛИКИ ПОЛЬША}

Аннотация: В статье рассматриваются категории и понятия, входящие в научный тезаурус системы усовершенствования учителей естественно-математических предме -

(c) Наталія Свтушенко, 2018 
тов Республики Польша. Описан полный и систематизированный перечень дефиниций для уточнения базового понятия «учитель». Автором обосновывается актуальность определения тезауруса системы усовершенствования учителей в научном пространстве Республики Польша - страны, которая входит в Европейский Союз - с иелью использования ее положительного опыта в прочессе развития системы повышения квалификации педагогов последипломного образования Украины.

Ключевые слова: учитель, учитель естественно-математических предметов, система усовершенствования учителей, подготовка учителей.

\section{Nataliia Yevtushenko}

An extended abstract of the paper on the subject

\section{"Scientific thesaurus of the system of training of teachers of natural sciences and mathematics in the Republic of Poland"}

Problem setting. Research of the system of teacher training of Polish teachers of natural sciences and mathematics acquires special significance from the point of view of the main factor of the growth of human capital of the country, the source of new ideas and guarantees of the dynamic development of the economy and society as a whole. The disclosure of the essence of this concept requires an understanding of the main categories and concepts that science has about the subject of research in the scientific space of the Republic of Poland. Consideration of the use of the scientific lexicon in the pedagogy of Poland, relating to the system of training of teachers of natural sciences and mathematics, will facilitate the accumulation of necessary information on the phenomenon under investigation, the reflection of the established links between the basic concepts.

Recent research and publications analysis. The professional training of Polish teachers was the subject of research by many scholars, in particular, a combination of theory and practice in the professional training of teachers $(N$. Kviatkovska, K. Lech, V. Okon); tendencies of pedagogical education of teachers (I. Shemprukh); organization of pedagogical practice (K. Duray-Novakova, M. Yakovytska, U. Novatska); the system of teacher training and the ways of its optimization (J. Moritz) were investigated.
Topics covered include such as research of different approaches to understanding the formation of a teacher, classical and alternative interpretation (A. Kozminskyi, A. Mashke, S. Michalovskyi, B. Sliveryskyi, etc.); the value of the teacher's personality in the innovative processes of its preparation (V. Zachinskyi, Z. Kvientsinskyi, Ch. Kupisievich, V. Lipke, $R$. Osovskyi, etc.); the peculiarities of the development of Polish education at the present stage (M. Herbst, J. Herchinskyi); organization of long life education (A. KlimKlymashevska, E. Kulia, M. Penkoska ).

Considerable attention in the scientific research is given to the problems of postgraduate education in the system of continuous professional training of teachers. In particular, the dissertation studies are devoted to the organizational and pedagogical conditions for vocational training in the centers of long life education in Poland (A. Mushynsky), including Ukrainian scholars who investigated the problem of vocational teacher training (A. Vasyliuk).

Paper objective The purpose of the article is to find out the essence of the concept of "the system of training of teachers of natural and mathematical subjects of the Republic of Poland" and systematization of the definitions that clarify its scientific thesaurus.

Paper main body. Scientific pedagogy in the field of Polish teachers training 
has its own thesaurus, which is constantly evolving and improving. Its formulation and reformulation in scientific concepts reflect the variability of the processes and phenomena of modern pedagogical education in Poland.

In our opinion, the scientific thesaurus of the subject area of "improvement of the qualification of teachers of natural and mathematical subjects of the Republic of Poland" includes such concepts as "teacher", "teacher of natural and mathematical subjects", "teacher training", "system of teacher training".

Summarizing different approaches to the interpretation of the notion of "teacher", we note that it is outlined in different contexts: in the broad social senseit is a person who passes knowledge, teaches how to live; in a pedagogical, narrower sense - a teacher is a specialist who professionally studies and educates others.

A distinctive feature of the teacher of natural and mathematical subjects is the requirements for education and upbringing, as well as the detailed components that follow from this process, such as organization of training, organization and management of the student collective, methods of transfer of knowledge, control and evaluation of students' work, organization of extracurricular activities, cooperation with the leadership of the school and the teaching staff, improvement and selfeducation, the availability of legal status, the presence of professional organization, professional publications, intellectual activity, the desire to progress at work, responsibility for the students.

The requirements put by the Polish state before the teachers of natural and mathematical subjects are quite high and are general and specific. In particular, for the qualitative performance of their professional functions, justification of public confidence in the education of the younger generation, the teacher must have profound knowledge of the subject, good professional training, proper skills and behav- ior, adequately developed level of social competencies.

Polish scholars define the concept of "professional development of teachers" as a continuous process that begins with the decision to choose a profession and lasts throughout the period of activity; an integral part of the teacher training, which is to increase the professional level through advanced training courses; result (product) of the learning process, which consists in increasing and changing the professional competence and qualifications of specialists, the development of the universal personality of a teacher; an important component of out-of-school education; an instrument for adapting the profession to young teachers and teachers throughout the pedagogical activity during the updating of the subject, pedagogical knowledge, in learning the achievements of science, in expanding or changing the specialty of specialists.

The goal of the teacher training system is implementation of "the challenges" facing modern Polish education, namely changes in the requirements which put forward by the public and the system of education to teachers, political, socioeconomic and demographic changes, changes in teacher qualifications arising from requirements that are related to the development of pedagogical sciences, as well as the improvement of the system of education itself.

Conclusions of the research. Thus, on the basis of the theoretical analysis of scientific sources, the thesaurus of the system of training of teachers of natural and mathematical subjects of the Republic of Poland was determined. The key characteristic of the system of development of Polish teachers of natural sciences and mathematics is revealed. The system of teacher development is an integral system, an important component of the system of out-of-school teacher training, the essence of which is revealed through consideration of its structural components (tasks, goals, 
organization, forms and methods). In addition to the external (out-of-school development), there is an improvement on the teacher's working place and an individual one in the form of self-education.

The systematization and refinement of the basic concepts of the system of training of teachers of natural sciences and

Постановка проблеми в загальному вигляді та ії зв'язок із важливими науковими чи практичними завданнями. Проблема професійного розвитку вчителів є однією з найбільш обговорюваних тем польського суспільства. Якість роботи вчителя оцінюється і перевіряється майже кожного дня учнями та суспільством [9]. Таке ставлення до представників цієї професії пояснюється особливою роллю вчителя у сучасному світі - жодна професійна група не має такого великого впливу на формування соціальної свідомості. Представники цієї професії повинні виправдовувати очікування та потреби суспільства, стимулювати та здійснювати освітні процеси в ім'я загальних інтересів, а не лише окремих осіб, бути незалежними та критичними [19].

Особливого значення набуває професійне вдосконалення вчителів природничо-математичних предметів із метою практичного втілення ідей шкільної реформи [3]. Саме природничоматематичні дисципліни значною мірою спрямовані на пізнання наукової картини світу, формування світоглядних позицій учнів, розвиток їх творчих якостей, логічного мислення, здатності до дослідницької діяльності, що значною мірою сприяє успішній адаптації людини у житті [3, с. 5].

Аналіз останніх досліджень і публікацій, у яких започатковано розв'язання цієї проблеми і на які спирається автор. Професійна підготовка польських учителів стала предметом дослідження багатьох учених, зокрема досліджувалося: поєднання теорії i mathematics of the Republic of Poland will contribute to the enrichment of the theoretical content of this concept, carrying out a comparative analysis of the basic concepts of the systems for improving the qualification of teachers of natural and mathematical subjects in postgraduate education in Ukraine and the Republic of Poland.

практики у професійній підготовці вчителів (Н. Квятковська, К.Лех, В. Оконь); тенденції розвитку педагогічної освіти вчителів (І. Шемпрух); організація педагогічної практики (К. Дурай-Новакова, М. Яковицька, У. Новацька); система професійної підготовки вчителя і шляхи iii оптимізації (Я. Морітз).

Висвітлено такі питання: дослідження різних підходів щодо розуміння системи формування вчителя, класичне i альтернативне тлумачення (А. Козьмінський, А. Машке, С. Михаловський, Б. Сліверський та ін.); значення особистості вчителя в інноваційних процесах щодо його підготовки (В. Зачинський, 3. Квєнцінський, Ч.Купісєвіч, В. Ліппке, Р. Осовський та ін.); особливості розвитку освіти Польщі на сучасному етапі (М. Гербст, Я. Герчинський); організація неперервної освіти (А. КлимКлимашевська, Е. Куля).

Значна увага у наукових дослідженнях приділяється проблемам післядипломної освіти в системі неперервної професійної підготовки вчителів. Зокрема є дисертаційні дослідження, присвячені організаційно-педагогічним умовам професійного навчання в центрах неперервної освіти Польщі (А. Мушинські), у тому числі українських науковців щодо проблеми професійнопедагогічної підготовки вчителів (А. Василюк).

Виділення не вирішених раніше частин загальної проблеми. Серед великої кількості досліджень щодо розвитку й функціонування педагогічної освіти Польщі система вдосконалення вчителів природничо-математичних пред- 
метів у післядипломній освіті Республіки Польща до цього часу поки не отримала достатнього висвітлення в науковій літературі. Важливість здійснення іiі дослідження посилюється можливістю використання досвіду польських колег стосовно модернізації професійної підготовки та неперервної освіти педагогів. Тому актуальним завданням сьогодні $\epsilon$ розкриття сутності наукового тезауруса вдосконалення польських фахівців завдяки розгляду основних понять і термінів, які його складають.

Формулювання цілей статті. Метою статті є 3'ясування сутності поняття «система вдосконалення вчителів природничо-математичних предметів Республіки Польща» і систематизування дефініцій, що уточнюють його науковий тезаурус.

Виклад основного матеріалу дослідження 3 повним обгрунтуванням отриманих наукових результатів. Загальновідомо, що науковий аналіз фактів, концепцій, явищ, процесів здійснюється 3 використанням тезауруса відповідної предметної області. Зокрема, апарат наукового тезауруса $\epsilon$ логікогносеологічним засобом, що дозволяє забезпечити здійснення пізнавального руху у процесі дослідження певного педагогічного явища [24]. Вивчення тезауруса як системи понять, яка призначена для їх засвоєння й актуалізації, здійснюється з метою успішної орієнтації у предметній площині наукових знань [5].

Під тезаурусом розуміється сукупність понять певної галузі науки, що відтворює обсяг і якість інформації, якою володіє наука про предмет дослідження. У системі педагогіки застосування наукового лексикону відображує зв'язки між словами певної мови, сукупність термінів, які належать до однієї чи кількох галузей знань зі встановленими термінами, зв'язками [5, с. 327].

Наукова педагогіка у сфері вдосконалення польських учителів має свій тезаурус, що постійно розвивається і вдос- коналюється. Його формулювання та переформулювання у наукових концепціях показують змінність процесів та явищ, що відбуваються у сучасній педагогічній освіті Польщі. Зазначимо, що одне і те ж поняття у наукових просторах різних країн наповнюється неоднозначним змістом і оформлюється відповідно у специфічні визначення-дефініції. Тому розуміння сутності «система вдосконалення вчителів природничо-математичних предметів у Республіці Польща», потребує розуміння основних категорійпонять, що використовуються у процесі дослідження цього педагогічного явища.

На нашу думку, тезаурус предметної області «підвищення кваліфікації вчителів природничо-математичних предметів Республіки Польща» включає наступні поняття: «учитель», «учитель природничо-математичних предметів», «удосконалення вчителів», «система вдосконалення педагогів», «підготовка вчителя».

Базовим поняттям системи вдосконалення вчителів природничоматематичних предметів Республіки Польща $\epsilon$ «вчитель» - «людина, яка займається навчанням інших» [22], «професійно займається освітою - навчанням, вихованням інших; педагог» [23]. На думку М. Османського, професія вчителя бере свій початок з глибокої давнини і $€$ однією 3 найстаріших у світі. Протягом століть вона зазнала численних перетворень і вдосконалень [17].

Сьогодні поняття «вчитель» трактується польськими дослідниками порізному: як людина, яка віддана певній ідеї та проголошує іiі (агітатор, апологет, активіст, експонент, проповідник, гуру, провісник, ідеолог, розповсюджувач, представник, першовідкривач, популяризатор, преторіанець, пропагандист, оратор, сіяч, послідовник, борець, поборник, розповсюджувач, оратор, послідовник); у шкільному контексті - викладач; як особа, яка передає знання (авторитет, репетитор, наставник, лідер, нау- 
ковий керівник, педагог, професор, викладач, еталон); як той, хто навчає у колишніх наказах (бакалавр, наставник, дидакт, вихователь, інструктор, наставник, тьютор); щодо вищої школи (доцент, лектор, академічний учитель, ведучий, той хто проводить навчання, той, хто проводить заняття, вихователь, викладач); як особа, яка передає знання комусь (коуч, демонстратор, інструктор, тренер); як особи, яка відповідальна за навчання (педагог-теоретик, наставник, ведучий, інструктор, стажер); у освітньому процесі (ад'юнкт, вихователь, лектор, доповідач, ведучий, референт, інформатор, викладач); як поважний вчитель (експерт, керівник, майстер, наставник, тренер); у значенні, що використовувалося у давнину (майстер, вихователь) [25].

За новим педагогічним словником (за ред. В. Оконь) «учитель» - це особа, яка передає знання, навчає жити в суспільстві. Вчитель навчає, виховує та розвиває учнів (дітей, підлітків, дорослих), що знаходяться під його опікою. Це значення сформульоване під впливом нових педагогічних тенденцій у результаті значної еволюції педагогічної думки. Воно наближає нас до більш важливого положення - вчитель стає таким, коли він розвивається. Робота вчителя залежить від його учнів, програм і освіти (тобто навчання та виховання), від зовнішніх умов, але, насамперед, від самого вчителя [18, с. 256$]$.

Польський науковець підкреслює, що «остання залежність обумовлена двома чинниками - це особистість учителя і його кваліфікація. Від особистості вчителя залежить його ставлення до роботи. Під постійним спостереженням учнів він стає для них зразком або ж навпаки. Бажаним взірцем стає особливо тоді, коли, не вважаючи себе досконалим учителем, він постійно працює над собою як людиною, як фахівцем і педагогом, коли керується у своєму житті своїми ідеалами та істинами добра i краси. Він любить своїх учнів, коли поважає їх волю і намагається підготувати ïх до життя» [18, с. 256].

В. Оконь уважає, що не менш значущою особистісною характеристикою педагога $є$ його кваліфікація. Важливим $€$ розуміння цілей навчання та виховання, вміння застосовувати потрібні методи та засоби, створювати відповідні умови, що дозволяють досягти бажаних змін у вихованців, здійснювати багатогранну педагогічну діяльність (когнітивну, емоційну та практичну), що одночасно сприяє розвитку самого вчителя. Обидва чинники є взаємозалежними. Перший, на думку науковця, має значний вплив на підготовку фахівців-кандидатів на посаду вчителя, розуміння власної ролі, самопізнання педагогів, але на який до цих пір мало звертають увагу в спеціалізованих закладах із підготовки фахівців, другий - на формування вчительських компетенцій, що підпорядковані безпосередньо розумінню власної ролі [18, с. 256].

На думку польської дослідниці Б. Сітарської, сучасний вчитель - це мудрий, критичний, чуйний і компетентний педагог. Це не тільки добрий спеціаліст, а й водночас розумний, відповідальний керівник i координатор, який уміє ставити учням (студентам) завдання, спрямовані на їх розвиток, також він мусить бути критичним стосовно власної дисципліни, постійно ставити перед собою вимоги щодо розв'язання основних проблем професійної діяльності [4]. Роль, яку виконує сучасний учитель, - це роль мислячого практика-новатора $\mathrm{i}$ водночас інтелектуала, який веде свідомо і професійно суспільно-педагогічну та культурну діяльність у школі та найближчому середовищі. Маючи на увазі виконання його фахової ролі, сучасного вчителя в Європі називають трансформативним інтелектуалом [4, с. 3].

Українська дослідниця Т. Кристопчук, вивчаючи педагогічну освіту у Республіці Польща, відмічає, що до кандидата на посаду вчителя ставляться вимо- 
ги, які стосуються як його кваліфікації, так і моральних характеристик та здоров'я [2]. Зокрема, Картою вчителя зазначається, що цю посаду може отримати тільки особа, яка, по-перше, має вищу освіту 3 відповідною педагогічною підготовкою або закінчила заклад із педагогічної підготовки і працює відповідно до отриманої кваліфікації, по-друге, дотримується основних моральних принципів i, по-третє, здоров'я якої відповідає нормам, що необхідні для здійснення професійних обов'язків [10].

Усі ці якості певною мірою формуються у майбутніх фахівців під час здобуття кваліфікації учителя в закладах спеціалізованої підготовки. Як зазначає дослідник Ч. Куписевич, майбутні вчителі беззастережно повинні опанувати певні завдання, які зазвичай включають передачу знань та досвіду, стимулювання пізнавальної та практичної діяльності, а також інноваційних здібностей, розвиток системи цінностей, формування ставлень і характеру, формування та розвиток інтересів, створення умов для об'єднання теорії та практики, підготовку до раціонального та систематичного самоконтролю, самооцінки напрямку та результатів власної роботи, до систематичного та самостійного навчання протягом усього життя, організацію соціального життя дітей та молоді у школі [15].

Узагальнюючи різні підходи до тлумачення поняття «вчитель», зазначимо, що воно окреслюється різними контекстами: у широкому суспільному значенні - особа, яка передає знання, навчає як потрібно жити; у педагогічному, більш вузькому значенні - це фахівець, який професійно займається навчанням i вихованням інших.

Розглянемо поняття «вчитель природничо-математичних предметів». Насамперед, аналіз кваліфікацій вчителів природничо-математичних предметів виявляє наявність різних кваліфікаційних рівнів фахівців, а саме: «академічний вчитель» (представники цих спеціа- льностей мають право викладати у вищих навчальних закладах); учитель професійного навчання молодших та середніх шкіл (крім учителів професійної освіти) та учитель початкової школи (фахівці 3 виховання молодших дітей). Відповідно до Постанови міністра праці та соціальної політики від 7 серпня 2014 року щодо класифікації професій та спеціальності для потреб ринку праці та іiі сфери застосування (Журнал законів від 2014 року, пункт 1145) відображені такі спеціальності вчителів природничоматематичних предметів: учитель біології (233001), учитель хімії (233002), учитель фізики і астрономії (233004), учитель географії (233005), учитель математики (233015) [11, с.40].

Відмінними рисами вчителя природничо-математичних предметів $\epsilon$ вимоги до надання освіти та виховання, а також детальні компоненти, що випливають 3 цього процесу: організація навчання, організація та управління учнівським колективом, методи передачі знань, контроль та оцінювання робіт учнів, організація позашкільної діяльності, співпраця 3 керівництвом школи та викладацькою групою, вдосконалення та самоосвіта, наявність юридичного статусу, професійної організації, професійних публікацій, інтелектуальної діяльності, прагнення до прогресу на роботі, відповідальність за вихованців [8].

Вимоги, які ставить польська держава перед учителями природничоматематичних предметів, досить високі. Зокрема, учитель математики повинен глибоко знати свій предмет, опанувавши такі знання та вміння: розуміння значення математики для суспільства та ii застосування, ролі і важливості доведення в математиці, а також припущення (гіпотези); будови математичних теорій, використання математичного апарату для побудови і аналізу простих математичних моделей в інших науках; знання основних теорем з відомих областей математики; основних прикладів, 
що ілюструють конкретні математичні поняття; вибраних понять і методів математичної логіки, теорії множин та дискретної математики, що містяться в основах інших дисциплін математики, а також вміння спростовувати помилкові гіпотези або неправдиві міркування тощо. Фахівець повинен мати навички здійснювати правильні математичні міркування, формулювати теореми і визначення, використовувати обчислення висловлювань і квантифікатори; правильно використовувати квантифікатори в повсякденній мові; знати процедури наведення простих і середньої складності доказів, володіти методом повної індукції; вміти визначити функції і рекурентні співвідношення; використовувати систему класичної логіки для формалізації математичних теорій тощо [20].

Спільними рисами для представників усіх спеціальностей $є$ визначені соціальні компетенції - усвідомлення рівня власних знань і розуміння необхідності подальшої освіти; уміння точно сформулювати запитання, що поглиблюють розуміння теми або відтворення втраченої частини міркування; уміння фахівців працювати в команді, розуміння необхідності систематичної роботи 3 усіх проектів, які мають довгостроковий характер; розуміння і оцінка важливості інтелектуального права власності у власній діяльності та діяльності інших людей; здатність діяти етично; розуміння необхідності популяризації видатних досягнень вищої математики; навички самостійного пошуку інформації в літературі, володіння іноземними мовами включно; уміння формулювати думки щодо основних завдань математики [20].

Суттєвою характеристикою представників учительської професії $\epsilon$ визнання вчителя «особистістю, яка безперервно удосконалюється, розвивається, таким чином підвищуючи свою професійну кваліфікацію» [24, с. 97]. Тому у польському педагогічному лексиконі іс- нує базове поняття «професійне вдосконалення вчителів».

Відомий польський дослідник Ч. Банах стверджує, що вдосконалення є інструментом адаптації до ситуації, що змінюється, та збагачення кваліфікації, який якнайкраще визначає потреби молодих учителів та способи організації самоосвіти і підвищення рівня їх майстерності [6]. Більшість польських науковців вдосконалення вчителів визначає як безперервний процес, що розпочинається від прийняття рішення про вибір професії й триває протягом усього періоду діяльності, до моменту виходу вчителя на пенсію [14]. Поняття «професійне удосконалення вчителів» також трактується і як результат цього навмисного, спланованого i безперервного процесу, що полягає у розширенні професійних компетенцій вчителів, підвищенні їх професійного рівня через курси підвищення кваліфікації [19], збільшенні та зміні професійної компетентності й кваліфікації, розвитку універсальної особистості вчителя [14].

Узагальнене визначення знаходимо у педагогічному словнику-лексиконі (українсько-англійсько-польський), що розкриває вдосконалення вчителів (пол. doskonalenie nauczycieli) як важливу складову системи позашкільної підготовки педагогів, яка полягає в наданні допомоги фахівцям-початківцям у період професійної адаптації, актуалізації знань із педагогіки та предмета викладання під час самостійної професійної діяльності, ознайомлені з новими здобутками науки, допомозі в розширенні або заміні спеціалізації, організації різних форм індивідуальної або колективної самоосвіти вчителів, наданні допомоги в самостійній дослідній праці [1].

Характеризуючи систему вдосконалення вчителів у Республіці Польща як цілісну систему, А. Коморнічак розкриває сутність цього поняття через її взаємопов'язані елементи (завдання, цілі, організацію, форми вдосконалення) [13]. 
Зокрема В. Оконь, визначаючи вдосконалення вчителів як важливу складову системи позашкільної підготовки педагогів, виділяє основні іiї завдання: надання допомоги молодим учителям в адаптації до професії, у період професійного самоствердження - оновлення предмета та педагогічних знань, ознайомлення 3 досягненнями науки, надання допомоги у поширенні або зміні спеціальності [18, с. 78$]$.

Цілі системи вдосконалення вчителів, на думку іншого дослідника Х.Дибек, розкриваються через реалізацію «викликів», що постають перед освітою - це зміни у вимогах, що висуваються до вчителів від громадськості й системи освіти, що відбуваються під впливом політичних, соціально-економічних та демографічних змін, у кваліфікації вчителя, які $\epsilon$ результатом вимог пов'язаних із розвитком педагогічних наук, а також вдосконалення самої системи освіти [8].

Організація системи вдосконалення польських учителів здійснюється через діяльність Центрального навчальновиховного центру, кураторів освіти, через воєводські центри вдосконалення, центри педагогічної творчості, відомчі центри професійного розвитку [12]. Центри вдосконалення $є$ установами, які навчають дорослих, реалізуючи ідею безперервної освіти. Вони працюють для певних професійних груп, що дозволяє слухачам вдосконалювати, доповнювати та оновлювати свою професійну кваліфікацію та набувати нових навичок [16].

Розгляд поняття «вдосконалення вчителів у Польщі» приводить до розуміння його як системи - «сукупності елементів і зв'язків, а також залежностей між ними, що утворює окреслену цілісність статичного або динамічного характеру» [18, с. 377]. Зокрема А. Крул, Т. Мішке, розкриваючи сутність системи вдосконалення вчителів, розглядають іiі як сукупність структурних компонентів і зазначають, що «окрім зовнішнього (позашкільного вдосконалення) $є$ вдосконалення за місцем роботи педагога та індивідуальне у формі самоосвіти» [14]. Підвищення фахового рівня педагогів відбувається шляхом їх участі в лекціях, конференціях, семінарах та обговореннях, що відкриті для спільного користування і у закладах післядипломної освіти, зокрема з метою отримання іншої спеціальності [21].

Серед принципів освітньої діяльності, які беруться до уваги в роботі спеціалізованих установ із підвищення кваліфікації вчителів у Республіці Польща, виокремлюють взаємозв'язок теорії і практики, змінюваність, різноманітність форм, безперервність, багатовимірність, багаторівневість, відкритість [7].

Можна відмітити, що однією 3 найпоширеніших форм удосконалення вчителів $є$ курси підвищення кваліфікації. Завдяки їх функціонуванню створюються широкі можливості щодо розвитку теоретичних і практичних навичок польських фахівців. Більшість із цих курсів підтримує розвиток учителів у напрямі реалізації інструментальних цілей освіти, що досягається впровадженням перевірених методик професійної практики (технічна підготовка, виховничо-опікунські навички і компетентності, психолого-педагогічна підготовка, компетентності в галузі інформаційних технологій).

Завданням таких курсів, що організовуються, зокрема для вчителів природничо-математичних предметів є: «підвищення ефективності навчання в галузі природничих предметів і математики; підтримка вчителів у діяльності, яка пов'язана $з$ функціонуванням шкіл у місцевих середовищах; підтримка вчителів у сприянні розвитку математичних і природних інтересів та здібностей учнів; поширення цілісного підходу у вивченні навколишнього світу; поліпшення інформаційно-комунікаційних технологій у роботі вчителів математики та природничих наук; спрямування здатності педагогів до формування соціально бажаних поглядів, таких як толерантність, надійність, 
комп’ютерна безпека та дії для постійного розвитку» [26, с. 1]. Вони мають вузьку спрямованість і короткий термін проходження від 12 до 18 годин. Їх тематика має досить різноманітний характер («Виховання мотивації учнів до роботи на уроках математики», «Е-навчання на платформі Moodle», «Новий основний навчальний план 3 математики», «Нові виклики в методології та дидактиці», «Як підготувати цікавий урок хімії в початковій школі» тощо). Учителі мають право на здійснення вибору за власним бажанням.

Як справедливо зазначає А. Коморнічак, у сучасній цивілізації, яка характеризується високими темпами розвитку науки і техніки, учитель повинен мати можливість використовувати представлені пропозиції у системі вдосконалення вчителів, іiі спеціалізованих установах. Але слід підкреслити той важливий та істотний факт, що всі інституції стають безпорадними, якщо вчитель не буде мати глибоко розвинених потреб та здатності постійно вдосконалювати свою кваліфікацію, керувати власним професійним розвитком та розвитком своєї особистості [13].
Висновки 3 даного дослідження та перспективи подальших розвідок. Отже, на основі теоретичного аналізу наукових джерел визначено тезаурус системи вдосконалення вчителів природничо-математичних предметів Республіки Польща. Розкрито ключову характеристику системи вдосконалення польських учителів природничо-математичних предметів. Система вдосконалення вчителів - це цілісна система, важлива складова системи позашкільної підготовки учителів, сутність якої розкривається завдяки з'ясуванні іiї структурних компонентів (завдання, цілі, організація, форми і методи). Окрім зовнішнього (позашкільне вдосконалення), існує вдосконалення за місцем роботи педагога та індивідуальне у формі самоосвіти.

Систематизація та уточнення базових понять системи вдосконалення вчителів природничо-математичних предметів Республіки Польща сприятиме збагаченню теоретичного змісту цього поняття, проведені порівняльного аналізу базових понять систем підвищення кваліфікації учителів природничо-математичних предметів у післядипломній освіті України і Республіки Польща.

\section{Список літератури:}

1. Василюк А. В., Танась М. Педагогічний словник-лексикон. Вид. 2-ге, уточ. й доповн. Ніжин : ПП Лисенко М. М. 2013. 224 с.

2. Кристопчук Т. С. Педагогічна освіта в Республіці Польща: структура та зміст. Неперервна професійна освіта за кордоном. 2013. С. 127-134.

3. Новацька У. Організація педагогічних практик студентів математичноприродничого відділу вищої педагогічної школи : автореф. дис. ... канд. пед. наук : спец. 13.00.04. «Теорія і методика професійної освіти» Інститут педагогіки і психології професійної освіти Академії педагогічних наук України. К. 2002. 24 с.

4. Сітарська Б. Теоретичні і методологічні засади дидактичних завдань $з$ педагогіки у процесі підготовки та вдосконалення вчителів : автореф. дис. на здобуття наук. ступеня док. пед. наук : спец. 13.00.04 «Теорія і методика професійної освіти» Київський національний університет імені Тараса Шевченка. К. 2005. 30 с.

5. Сисоєва С. О., Соколова I. В. Проблеми непервної освіти: тезаурус наукового дослідження: наук. видання НАПН України, Ін-т педагогічної освіти і освіти дорослих, МОН. Маріупольський держ. Гуманітарний ун-т. К. : ЕКМО. 2010. 362 с.

6. Banach Cz. Kształcenie, dokształcanie i doskonalenie nauczycieli. Encyklopedia Pedagogiczna. red. W. Pomykało. Warszawa : Fundacja Innowacja.. 1993. 295 s. 
7. Buczkowska-Gola M. Wymagając od ucznia, wymagajmy od siebie. Edukacja i dialog. 2000. № 6. S. 46-49.

8. Dybek H. Doradztwo metodyczne i doskonalenie zawodowe nauczycieli. Kraków : Akademicka Oficyna Wydawnicza IMPULS. 2000. 204 s.

9. Kautz T. Przegląd systemu kształcenia nauczycieli w Polsce w latach 1945-2010. Zeszyty naukowe akademii marynarki wojennej. 2011. № 2 (185). S. 187-202.

10. Karta nauczyciela po zmianach z 6 grudnia 2007 r. Poznań : Oficynf Ekonomiczna Wydawnictwa. 2008. $52 \mathrm{~s}$.

11. Klasyfikacja zawodów i specjalności na potrzeby rynku pracy. Warszawa : Ministerstwo Pracy i Polityki Społecznej. 2014. 553 s.

12. Klim-Klimaszewska A. Formy doskonalenia nauczycieli. Doskonalenie kwalifikacji zawodowych nauczycieli. red. K. Śegnałka, B. Sitarska, A. Petrulyte. Siedlce : Akademia Podlaska. 2001. 153 s.

13. Komorniczak A. Znaczenie doskonalenia nauczycieli w ich rozwoju zawodowym.: [Електронний ресурс]. Режим доступу: http://www.edukacja.edux.pl/p7445-znaczenie-doskonalenia-nauczycieli-w-ich.php.

14. Król A., Miszke T. Model doskonalenia kadr szkół zawodowych w trzech krajach partnerskich [Model for the development of vocational schools in three partner countries]. Obrazovanie cherez vsju zhizn' : nepreryvnoe obrazovanie v interesah ustojchivogo razvitija. 2013. №1. S. 32-36.

15. Kupisiewicz Cz. Dydaktyka ogólna. Warszawa: Oficyna Wydawnicza GRAF PUNKT. 2000. 304 s.

16. Ministerstwo Edukacji Narodowej: o doskonaleniu nauczycieli [oprac. D. Obidniak, przy współpr. A. Pery]. Biblioteczka reformy, 4. Warszawa : MEN. 1999. 56 s.

17. Ochmański M. Teoria i praktyka pedagogicznego kształcenia nauczycieli red. M. Ochmański Lublin : UMCS. 1991. $221 \mathrm{s.}$

18. Okon W. Nowy slownik pedagogiczny. Warszawa : Zak. 2001. 468 s.

19. Prokopiuk W. Samokształcenie nauczycieli w kontekście humanistycznego paradygmatu. Białystok : Totus. 1998. $238 \mathrm{~s}$.

20. Rozporządzenie Ministra nauki i szkolnictwa wyższego z dnia 4 listopada $2011 \mathrm{r}$. W sprawie wzorcowych efektów kształcenia (Dziennik Ustaw Rzeczypospolitej Polskiej, Warszawa, dnia 24 listopada 2011 r. nr 253 poz. 1521).

21. Rozporządzenie Ministra Edukacji Narodowej z dnia 26 października 2012 r. zmieniające rozporządzenie w sprawie placówek doskonalenia nauczycieli (Dziennik Ustaw Rzeczypospolitej Polskiej, Warszawa, dnia 30 października 2012 r. nr 0 poz. 1196).

22. Słownik języka polskiego:[Електронний pecypc]. PWN. Режим доступу: https://sjp.pwn.pl/sjp/nauczyciel;2487580.html.

23. Słownik języka polskiego:[Електронний pecypc]. SJP. Режим доступу : https://sjp.pl/nauczyciel.

24. Stopińska-Pająk A. Edukacja dorosłych. Doradca zawodowy. Rynek pracy. Warszawa : WSiP, 2006. $347 \mathrm{~s}$.

25. Synonim.Net : [Електроннй pecypc]. Режим доступу : https://synonim.net/synonim/nauczyciel.

26. Wrocławskie Centrum Doskonalenia Nauczycieli : [Електронний ресурс]. WCDN. Wiedza ukierunkovana. Режим доступу : http://www.wcdn.wroc.pl/. 


\section{References:}

1. Vasyliuk A., Tanas' M. (2013). Pedahohichnyj slovnyk-leksykon (ukrains'ko-anhlopol's'kyj) [Teaching vocabulary dictionary (English-Ukrainian-Polish)] Nizhyn, Vydavets' PP Lysenko M. M., 224 p. [in Ukrainian].

2. Krystopchuk T. Ye. (2013) Pedahohichna osvita v Respublitsi Pol'scha: struktura ta zmist [Pedagogical education in the Republic of Poland: structure and content] Neperervna profesijna osvita za kordonom, vol. 5, pp. 127-134. [in Ukrainian].

3. Novats'ka U. (2002) Orhanizatsiia pedahohichnykh praktyk studentiv matematychno-pryrodnychoho viddilu vyschoi pedahohichnoi shkoly [Organization of pedagogical practices of students of the mathematical-natural department of the higher pedagogical school] Kyiv, 24 p. [in Ukrainian].

4. Sitars'ka B. (2005) Teoretychni i metodolohichni zasady dydaktychnykh zavdan' z pedahohiky u protsesi pidhotovky ta vdoskonalennia vchyteliv [Theoretical and methodological principles of didactic tasks in pedagogy in the process of teacher training and improvement] Kyiv, 30 p. [in Ukrainian].

5. Sysoieva S. O. (2010) Problemy nepervnoi osvity: tezaurus naukovoho doslidzhennia [Problems of non-primary education: thesaurus of scientific research] Kyiv, EKMO, 362 p. [in Ukrainian].

6. Banach Cz. (1993) "Kształcenie, dokształcanie i doskonalenie nauczycieli", Warszawa, Fundacja Innowacja, 295 s. [in Polish]

7. Buczkowska-Gola M. (2000) "Wymagając od ucznia, wymagajmy od siebie", Edukacja i dialog, vol. 6, pp. 46-49. [in Polish]

8. Dybek H. (2000). "Doradztwo metodyczne i doskonalenie zawodowe nauczycieli", Kraków, Akademicka Oficyna Wydawnicza IMPULS, 204 s. [in Polish]

9. Kautz T. (2011). "Przegląd systemu kształcenia nauczycieli w Polsce w latach 1945-2010”, Zeszyty naukowe akademii marynarki wojennej, vol. 2 (185), pp. 187-202. [in Polish]

10. Karta nauczyciela po zmianach z 6 grudnia 2007 r (2008), Poznań, Oficynf Ekonomiczna Wydawnictwa, 52 s. [in Polish]

11. Klasyfikacja zawodów i specjalności na potrzeby rynku pracy (2014), Warszawa, Ministerstwo Pracy i Polityki Społecznej, 553 s. [in Polish]

12. Klim-Klimaszewska A. (2001). "Formy doskonalenia nauczycieli”, Siedlce, Akademia Podlaska, 153 s. [in Polish]

13. Komorniczak A. "Znaczenie doskonalenia nauczycieli w ich rozwoju zawodowym", Portal edykacyjny edux.pl, available at : http://www.edukacja.edux.pl/p-7445znaczenie-doskonalenia-nauczycieli-w-ich.php. [in Polish]

14. Król A. "Model doskonalenia kadr szkół zawodowych w trzech krajach partnerskich" [Model for the development of vocational schools in three partner countries] Obrazovanie cherez vsju zhizn' : nepreryvnoe obrazovanie v interesah ustojchivogo razvitija. - 2013. - №1 . S. 32-36.

15. Kupisiewicz Cz. (2000). "Dydaktyka ogólna”, Warszawa, Oficyna Wydawnicza GRAF PUNKT, 304 s. [in Polish]

16. Ministerstwo Edukacji Narodowej: o doskonaleniu nauczycieli (1999). Biblioteczka reformy, 4, Warszawa, MEN, 56 s. [in Polish]

17. Ochmański M. (1991). "Teoria i praktyka pedagogicznego kształcenia nauczycieli”, Lublin, UMCS, 221 s. [in Polish]

18. Okon W.( 2001). Nowy slownik pedagogiczny", Warszawa, Zak, 468 s.

19. Prokopiuk W. (1998). "Samokształcenie nauczycieli w kontekście humanistycznego paradygmatu”, Białystok, Totus, 238 s. [in Polish] 
20. Rozporządzenie Ministra nauki i szkolnictwa wyższego z dnia 4 listopada $2011 \mathrm{r}$. W sprawie wzorcowych efektów kształcenia (Dziennik Ustaw Rzeczypospolitej Polskiej, Warszawa, dnia 24 listopada 2011 r. nr. 253 poz. 1521). [in Polish]

21. Rozporządzenie Ministra Edukacji Narodowej z dnia 26 października $2012 \mathrm{r}$. zmieniające rozporządzenie w sprawie placówek doskonalenia nauczycieli (Dziennik Ustaw Rzeczypospolitej Polskiej, Warszawa, dnia 30 października 2012 r. nr. 0 poz. 1196). [in Polish]

22. Słownik języka polskiego, PWN, available at: https://sjp.pwn.pl/sjp/nauczyciel; 2487580.html. [in Polish]

23. Słownik języka polskiego, SJP, available at : https://sjp.pl/nauczyciel. [in Polish]

24. Stopińska-Pająk A. (2006). "Edukacja dorosłych. Doradca zawodowy. Rynek pracy", Warszawa, WSiP, 347 s. [in Polish]

25. Synonim.Net, available at: https://synonim.net/synonim/nauczyciel. [in Polish]

26. Wrocławskie Centrum Doskonalenia Nauczycieli, WCDN. Wiedza ukierunkovana, available at : http://www.wcdn.wroc.pl/. [in Polish]

Стаття надійшла до редколегії: 15.02.2018 